\title{
PENERAPAN BARCODE SCANNER SYSTEM DALAM PROSES PENGUJIAN BAN DI LABORATORIUM UJI PT XYZ
}

\author{
Agus Mulyono \\ Fakultas Teknik, Prodi Teknik Industri Universitas Pamulang \\ dosen02255@unpam.co.id
}

\begin{abstract}
ABSTRAK
Pengujian produk adalah salah satu bagian penting dalam proses pengembangan produk baru dan merupakan kegiatan yang dijadwalkan / pengawasan untuk memastikan kualitas semua produk berada dalam standar yang ditentukan. Setiap perusahaan selalu berusaha untuk meningkatkan laba yang diterimanya melalui program untuk meningkatkan kualitas produk dan membuat efisiensi dalam setiap proses.Tahapan dalam pengujian ban dimulai dengan penerimaan, persiapan, pelaksanaan pengujian dan pembuatan laporan hasil pengujian. Dalam pengelolaan sampel uji ban harus dilakukan dengan cepat dan tepat. Jika proses pengelolaan sampel ban tidak dalam sistem yang baik, petugas pelaksana (operator) akan membutuhkan banyak waktu untuk memasukkan atau menuliskan data ban dan jenis pengujian yang dilakukan. Oleh karena itu, perlu untuk mentransfer kegiatan perekaman dari sistem manual ke sistem baru menggunakan pemindai barcode.

Berdasarkan hasil analisis yang telah dilakukan, penerapan sistem baru menggunakan barcode dapat membantu proses penerimaan data dan melaporkan hasil pengujian lebih efisien. Status uji sampel ban dapat dilihat secara waktu nyata dan mudah untuk menganalisis data yang diperlukan. Sistem barcode dapat mencegah kesalahan dan menghemat waktu karena menyediakan fitur untuk merekam cepat dan menguji data dapat diintegrasikan dari apa yang sebelumnya terpisah
\end{abstract}

Kata Kunci: Kualitas, Pengujian, Ban, Barcodes, Scanners.

\section{PENDAHULUAN}

Ban adalah salah satu komponen yang paling vital dari kendaraan karena merupakan satu-satunya bagian yang bersentuhan langsung dengan jalan. Karena menjadi bagian kendaraan yang menjadi komponen utama dalam keselamatan maka produsen ban memberikan perhatian utama dalam aspek pengendalian kualitas karena produk yang cacat dapat memberi potensi kegagalan fungsi ban pada kendaraan yang dapat menyebabkan kerugian besar bagi perusahaan dalam hal uang dan citra merek.

Produsen ban juga beroperasi di lingkungan yang sangat tidak stabil di mana spesifikasi ban dan permintaan mereka berkembang mengikuti teknologi dan kompetisi dengan para pesaing. Dalam menghadapi era persaingan global yang semakin kompetitif maka setiap perusahaan dituntut harus mampu melakukan gerakan efisiensi dalam setiap tahapan dalam proses pengembangan produk baru maupun produksi rutinnya.

Pengujian produk adalah bagian penting dalam siklus pengembangan dan pembuatan produk untuk memastikan bahwa produk baru yang sedang dalam pengembangan maupun produk yang sudah dijual ke pasar selalu dalam level kualitas yang telah ditetapkan. Proses pengujian produk yang cepat dan tepat menjadi elemen penting dalam perusahaan manufaktur.

Konsekwensi positif dalam usaha atau bisnis apabila proses pengujian produk baru dan pengawasan terhadap produk massal ditangani secara cepat dan tepat maka produk baru yang dikembangkan dapat segera diketahui level kualitasnya untuk segera dapat dijual ke pasar bila telah memenuhi target performa yang disyaratkan. Adapun pengujian produk dalam tujuan pengawasan kualitas terhadap produk yang sudah dijual massal ke pasar dapat dikontrol level kualitasnya agar selalu dalam rentang kualitas yang telah ditetapkan.

Kegiatan pengujian yang cepat dan tepat pada akhirnya berkontribusi terhadap kegiatan produksi yang lebih efisien sehingga produk dapat menjadi lebih kompetitif.

Menurut SNI (Standar Nasional Indonesia), Pengertian Kualitas adalah keseluruhan ciri dan karakteristik produk atau 
jasa yang kemampuannya dapat memuaskan kebutuhan, baik yang dinyatakan secara tegas maupun tersamar. Istilah kebutuhan diartikan sebagai spesifikasi yang tercantum dalam kontrak maupun kriteria-kriteria yang harus didefinisikan terlebih dahulu.

Kualitas tidak terlepas dari manajemen kualitas dari perencanaan lini produk dan fasilitas, sampai penjadwalan dan memonitor hasil akhir produk.

\section{DASAR TEORI}

Barcode adalah "Kode yang dapat dibaca mesin dalam bentuk angka dan pola garis paralel dengan lebar yang berbeda-beda, dicetak untuk identifikasi suatu produk secara unik. Secara umum penggunaan sistem barcode telah memberikan banyak manfaat bagi bisnis dan organisasi karena mampu memberikan peningkatan dalam produktivitas dan efisiensi yang signifikan bila dibandingkan dengan sistem manual. Dalam kegiatan bisnis dan organisasi sistem barcode digunakan dalam melacak produk, harga, status dan tingkat stok untuk manajemen terpusat dalam sebuah sistem perangkat lunak computer yang bisa diakses informasinya secara "real time" dan bias terhubung secara global.

Kode batang atau barcode dibaca mesin yang terdiri atas susunan garis vertikal hitam dan putih dengan ketebalan yang berbeda, sangat sederhana tetapi sangat berguna untuk menyimpan data-data spesifik misalnya kode produksi, tanggal kadaluwarsa, dan nomor identitas dari suatu produk.

Penggunaan barcode 1D hanya dapat menampung maksimal 85 karakter, maka seiring dengan perkembangan teknologi pemindai maka saat ini terjadi penurunan kebutuhan dan permintaan untuk barcode 1D yang berbanding terbalik dengan tingkat permintaan 2D barcode.

Pengembangan teknologi 2D barcode meningkatkan performansi dalam hal menyimpan lebih dari 7.000 karakter, memungkinkan untuk mengirimkan hampir dua paragraf informasi. Dengan penggunaan ke barcode 2D, kegiatan bisnis yang komplek dapat lebih terwakili karena dapat menyampaikan informasi yang jauh lebih rumit dan banyak, seperti tanggal mulai dan selesainya kegiatan operasi, kedaluwarsa, nomor seri, dan hal lainnya tanpa perlu pemindaian tambahan.

\section{METODE PENELITIAN DAN PERANCANGAN}

Perancangan sistem disusun dengan model terstruktur secara linier mengikuti alur proses pelaksanaan pengujian. Dengan model flowchart seperti dalam gambar 1 .

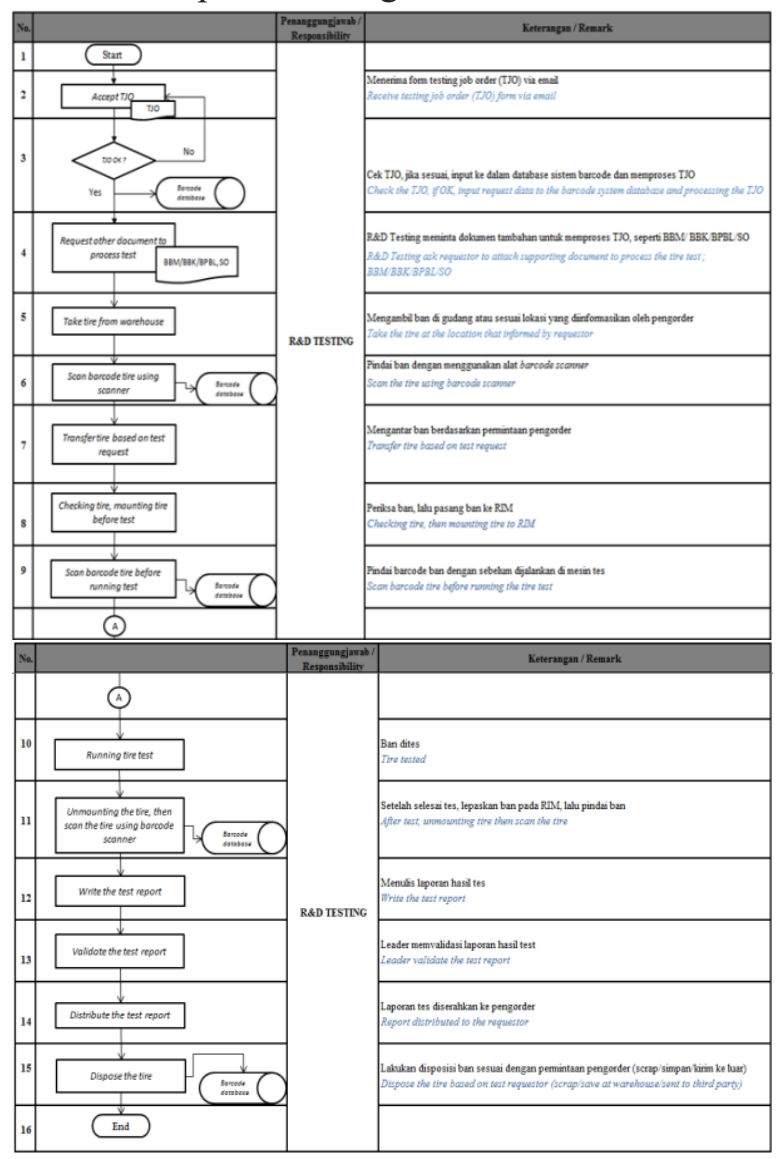

Gambar 1. Diagram alur proses pelaksanaan pengujian ban

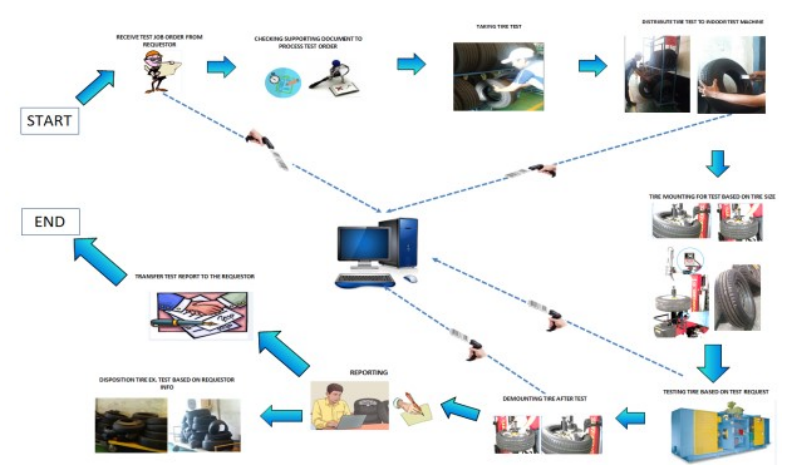

Gambar 2. Alur proses penggunaan barcode scanner dalam pengujian.

Hardware dan software yang dipakai dalam implementasi sistem barcode dapat dijelaskan sebagai berikut : 
1. Scanner type Datalogic Memor X3 untuk merekam data proses dalam pengelolaan ban uji dan proses pengujian.

2. Access Point type RB433AH / level 5, spesifikasi :

- 1 x Wlan R52HnD (ABGN 400mWatt) Poe (passive Over Ethernet)

- $\quad$ Adapter 24V /2A, 2 x 2.4Ghz 9dBi N-Type Male Omni Antenna Indoor Box 433U

- 2 Set D-Link Switch Unmanaged [DGS-1005A]

- 2 UTP Cat5E Belden USA (roll).

3. SOFTWARE

- Web base application : ASP

- Desktop application : Foxpro

- Database application : MYSQL

\section{IV.HASIL DAN PEMBAHASAN}

Pengembangan software untuk aplikasi sistem barcode yang diterapkan dengan tampilan menu seperti pada gambar 3 .

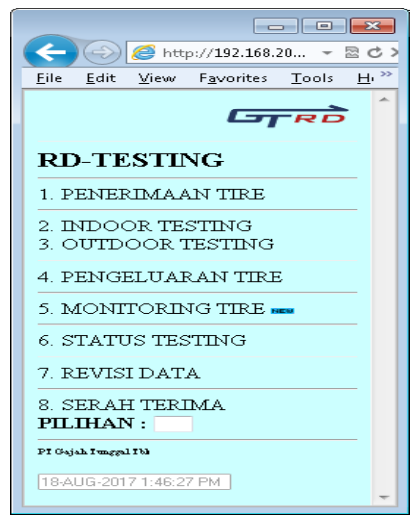

Gambar 3. Tampilan menu utama untuk akses sistem barcode

Penerimaan Tire adalah menu untuk merekam semua data ban yang diterima dalam pengujian dan mengidentifikasi tujuan dari pengujian berdasarkan Formulir Testing Job Order yang diterima.

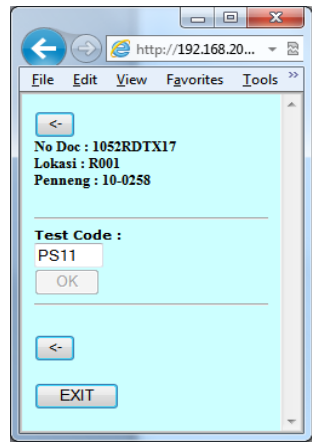

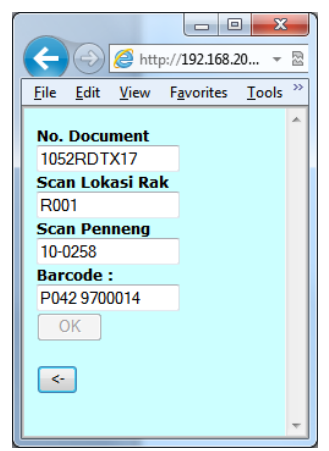

Gambar 4 \& 5. Tampilan menu "Penerimaan Tire"

Menu pengujian ban Indoor dan Outdoor digunakan untuk merekam awal dan akhir sebuah kegiatan pengujian.

Langkah - langkah dalam menggunakan menu ini adalah sebagai berikut :

1. Operator memindai ID mereka (no unik karyawan/Penneng) dan memindai barcode ban yang diuji, seperti ditunjukkan gambar 6.

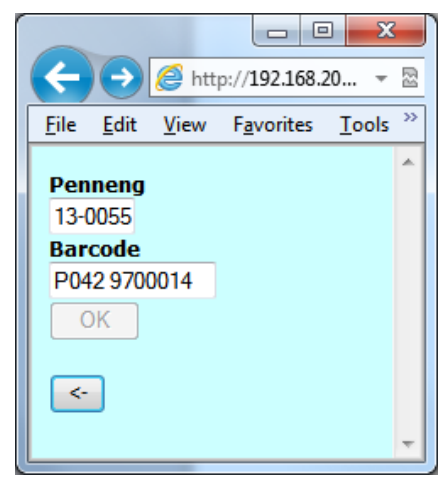

Gambar 6. Scan ID dari pelaksana pengujian (operator test).

2. Pelaksana pengujian (operator) memasukkan data nama mesin, kode test (Item test) dan kode rim.

3. Status ban dalam proses pengujian akan secara otomatis berubah menjadi sedang dalam pengujian.

4. Ketika ban yang diuji sudah selesai proses pengujiannya, maka pelaksana pengujian cukup menginput selesai. 


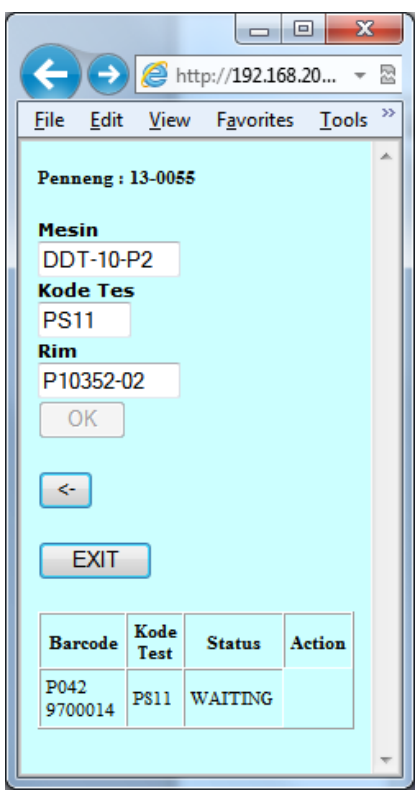

Gambar 7. Tampilan menu pengujian untuk tahapan test 2, 3 dan 4 .

Pengeluaran ban uji dilakukan dengan deskripsi pada tampilan menu seperti pada gambar 8. Fungsi dari menu ini adalah untuk penanganan akhir ban setelah pengujian selesai (Scrap, Re test, Cut atau disimpan di Warehouse).

Tahapan dalam "Pengeluaran Ban" adalah :

1. Pemindaian ID pelaksana pengujian

2. Memasukkan nomor "Testing Job Order"

3. Pemilihan tindakan lanjut untuk "Scrap, Retest, Cut or keep in warehouse".

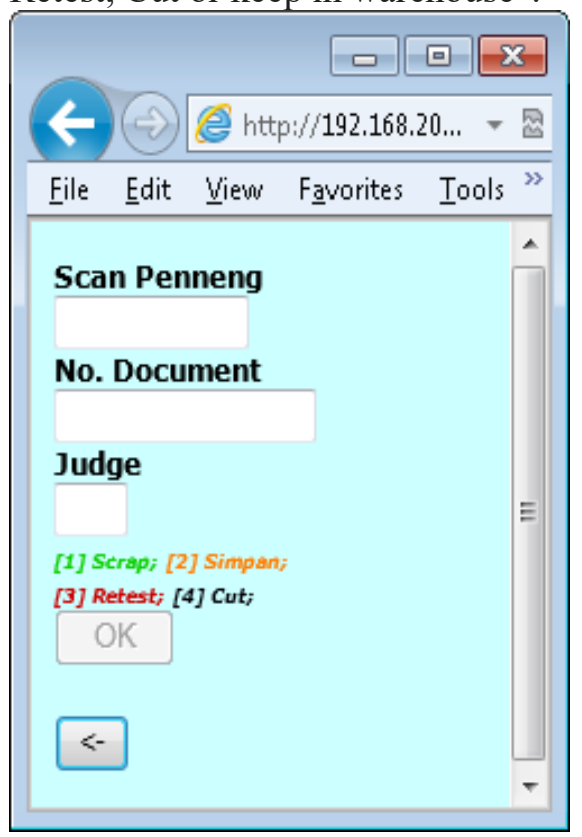

Gambar 8. Tampilan menu "Pengeluaran Ban"

Pemantauan ban uji.
Untuk pemantauan ada beberapa opsi yang isa digunakan diantaranya :

\section{Penerimaan Ban}

Semua informasi ban saat ban diterima dalam pengujian, menu ini dapat menunjukkan kapan formulir pesanan tiba, kapan ban ditangani, dan kapan ban dikirim ke fasilitas pengujian.

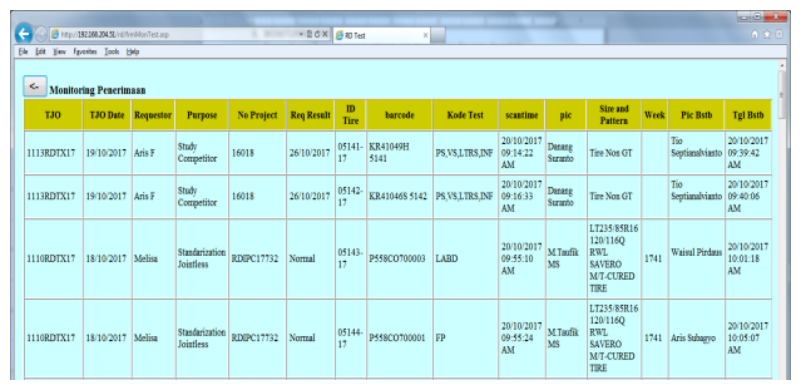

Gambar 9. Pemantauan ban uji menggunakan menu "penerimaan ban".

\section{Pelaksanaan Indoor Test}

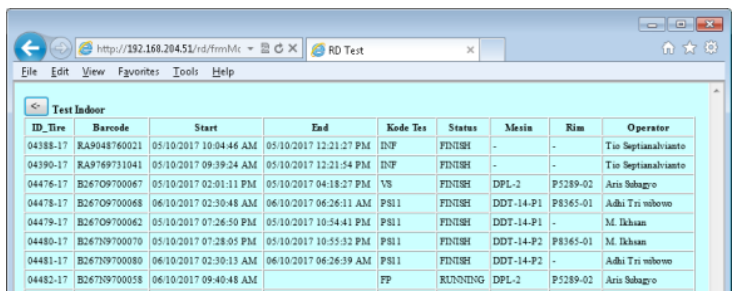

Gambar 10. Pemantauan ban uji menggunakan menu "Indoor Test".

\section{Pelaksanaan Outdoor Test}

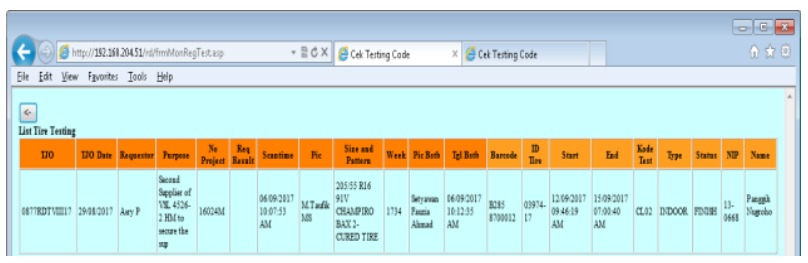

Gambar 11. Pemantauan ban uji menggunakan menu "Outdoor Test".

\section{Pengeluaran}

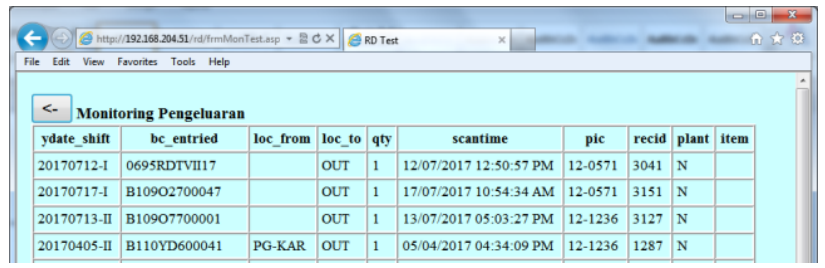

Gambar 12. Pemantauan ban uji menggunakan menu "Pengeluaran". 
Status Ban Uji

Fungsi untuk menu ini adalah untuk melacak dan mengetahui kondisi ban uji yang diminta. Ada dua opsi:

1. Dengan nomor Testing Job Order (TJO)

2. Dengan barcode ban uji.

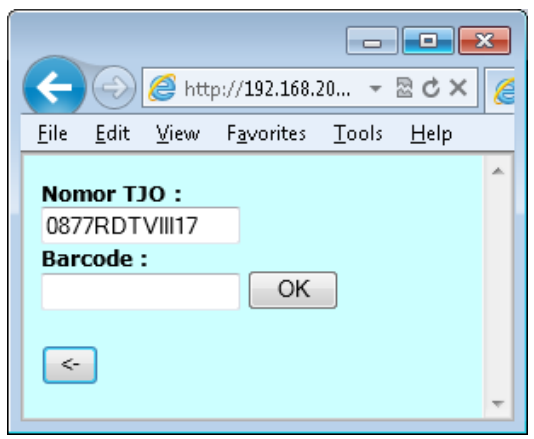

Gambar 13. Tampilan menu untuk mengetahui status ban uji yang diminta.

\section{V.KESIMPULAN}

Hasil dari penerapan sistem baru menggunakan sistem barcode dapat membantu proses penerimaan data dan pelaporan hasil pengujian lebih efisien. Status uji sampel ban dapat dilihat secara waktu nyata dan mudah untuk menganalisis data yang diperlukan. Sistem barcode dapat mencegah kesalahan dan menghemat waktu karena menyediakan fitur untuk merekam data atau informasi ban uji secara cepat dan status terkini dari ban uji dalam sistem menjadi terintegrasi dari apa yang sebelumnya terpisah-pisah.

\section{DAFTAR PUSTAKA}

Ramadijanti, N dan Setiawardhana. 2010. Implementasi Pengolahan Citra Untuk Identifikasi Produk Kemasan Berdasarkan Label Kemasannya. Surabaya.

Pressmen, R. (2010). RekayasaPerangkat Lunak (Buku Satu).Yogyakarta: Andi Publisher

Youllia, \& Indrawaty. (2001). Sebuah Gagasan Penggunaan Sistem Pengkodean Baris (Bacode) Sebagai Kunci Pendeteksian Uang Secara Otomatis. Jakarta.

Bambang, D dan M. Awaluddin. 2010. Penajaman dan Segmentasi Citra pada Pengolahan Citra Digital. Bandung

Ari, S.P dan Koredianto, U. 2009. Deteksi Kebakaran Berbasis Webcam Secara Realtime dengan Pengolahan Citra Digital. Bali

Kwak, Y. H., \& Anbari, F. T. (2006). Benefits, obstacles, and future of six sigma approach. Technovation, 26(5), 708-715.

"How Barcodes Work". Stuff You Should Know. 4 June 2019. Retrieved 5 June 2019.

Keyes, John (22 August 2003). "KarTrak". John Keyes Boston photoblogger. Images from Boston, New England, and beyond. John Keyes. Archived from the original on 10 March 2014. Retrieved 26 May 2013.

David L. Hecht. "Printed Embedded Data Graphical User Interfaces" Archived 3 June 2013 at the Wayback Machine. Xerox Palo Alto Research Center. IEEE Computer March 2001 
E. Burke, Harry. "Automating Management Information Systems:

Barcode Engineering and Implementation" Thomson Learning, ISBN 0-442-20712-3.

Zieger, Anne (October 2003). "Retailer chargebacks: is there an upside? Retailer compliance initiatives can lead to efficiency". Frontline Solutions. Archived from the original on 8 July 2012. Retrieved 2 August 2011. 